\title{
Teaching Critical Understandings of Realism through Historical War Simulations
}

\author{
Elizabeth Mendenhall, University of Rhode Island \\ Tarek Tutunji, Johns Hopkins University
}

ABSTRACT This article presents a simple modular simulation for teaching the advantages and limitations of Realist theory in an introductory international relations course. The advantages of this simulation include low preparation time, minimal resource requirements, and ease of integration with existing curricula. The game design is built around Kenneth Waltz's "three-image" framework for analyzing international politics, in a way that increases scenario complexity but not game difficulty. The article describes the full simulation process, from game design and implementation through debriefing and assessment. Two historical simulations were conducted: the first helped students to understand Realism and the second helped them to see its limitations. The article concludes with a discussion of the results of a voluntary, anonymous postgame survey that is intended to assess achievement of our learning objective.



his article provides an example of a simple yet sophisticated single-session simulation that can be used to teach Realism and its limitations in introductory international relations (IR) courses. The simulation is modular, minimizes the burden of preparation, maximizes individual student involvement, and is adaptable for diverse classroom environments. Our primary learning objective was to provide students a thorough and nuanced understanding of Realist theory and, in particular, an opportunity to investigate the connections between Realist assumptions about motivation and state behavior and outcomes in international politics.

Most introductory IR courses begin by teaching students about Realism as a theory of IR (Biersteker 2009, 315). As a theory, Realism is a description of and prescription for state behavior. It paints a tragic picture of international politics, in which war is sometimes inevitable despite the best efforts of individual actors (Morgenthau [1948] 2006; Schweller 1997). Contemporary accounts of Realism begin with the premise of international anarchy, in which the intentions of other actors are uncertain. They therefore prescribe that states pursue a policy of security maximization (Mearsheimer 2001). The most successful simulations are tailored to the goals of a particular course and designed to

Elizabeth Mendenhall is assistant professor of marine affairs and political science at the University of Rhode Island. She can be reached at mendenhall@uri.edu.

Tarek Tutunji is a PhD candidate in international relations at Johns Hopkins University. He can be reached at ttutunj1@jhu.edu. maximize the attainment of specific learning objectives (Glazier 2011; Smith and Boyer 1996). The challenge was in designing the rules of the game to help students understand Realism while leaving space for them to consider its limitations.

We built our simulation with reference to existing game designs intended to teach Realism. These simulations heavily embed the theory's assumptions about international politics in their design, often unreflectively. For example, Bridge and Radford (2014) used an online version of the game Diplomacy to illustrate multiple IR theories. However, as Asal $(2005,368)$ pointed out, Diplomacy is designed so that gameplay implicitly and explicitly reflects and reinforces Realist expectations about state behavior by putting players in a situation in which conflict and competition are necessary courses of action and priorities are fixed. In other games designed to teach Realism, students are told that security is paramount, possible moves are mostly military, intra-polity interactions are absent or uniform, and inter-polity interactions are highly simplified (Chapin 1998; Newmann and Twigg 2000; Reilly 2003). Existing simulations designed to teach Realism effectively convey core aspects of Realist theory but can lead students to believe that Realist assumptions about how the world works are unchangeable facts. Consequently, these simulations do not provide opportunities for seeing Realism's limitations and may lead students to wrongly believe that Realism is the only accurate representation of international politics (Sampson 2002; Sjoberg 2012).

We designed a simulation that teaches students Realist theory and gives them opportunities to critically reflect on it. Achieving 
both of these goals required two innovative design features. First, we did not restrict possible moves. For example, teams could play the entire game without entering into conflict or competition with one another. Second, we ran two simulations, one in which students were more tightly constrained by Realist assumptions model of international politics and allowed for the possibility of "two-level" games, transnational identity-based solidarity, and domestic power struggles. The three-image framework also had utility for gameplay: it provided a simple way for students and instructors to remember the rules of the simulation. Individual

\section{We designed a simulation that teaches students Realist theory and gives them opportunities to critically reflect on it. Achieving both of these goals required two innovative design features.}

about state priorities, and a second that gave students opportunities to decide what is important to them in decision making. This presented them with a situation in which they could reflect on the consequences of adopting Realist priorities and strategies.

The following sections describe the process of designing, implementing, and debriefing this simulation. We conclude with an assessment and suggestions for future simulations.

\section{GAME DESIGN}

The preexisting structure of our introductory IR course set the basic parameters for game design. Factors that should be considered include the likely number of students, the length of class sessions, the distribution of themes and historical events in course material, and the amount and type of readings assigned (Asal and Blake 2006; Asal and Kratoville 2013; Wedig 2010). For our purposes, this meant designing a role-play simulation for 50 -minute sections of about 20 students each. We limited the simulation to in-class time and the required readings, which preempted student concerns about extra work and reduced the burden of preparation for both students and instructors (Baranowski and Weir 2015; Giovanello, Kirk, and Kromer 2013; Glazier 2011). This required a game design that could be quickly and easily grasped by students and that covered the most important course content.

We ran a total of eight simulations: two scenarios in each of four sections. From a number of historical conflicts, we chose the Peloponnesian War and World War I for four main reasons. First, the readings for those weeks lent themselves to the assignment of nuanced and interesting roles (Kagan 2004, 31-151, 400-408; MacMillan 2014, 544-632; Remarque and Wheen 1991, 98-137; Stoessinger 2011, 3-28; Thucydides [1954] 1972, 2-3). Second, the details of these conflicts were sufficiently complex and unfamiliar for students that we could avoid preconceived notions of the causes and righteousness of the wars (Asal and Blake 2006, 7). Third, these wars fell at convenient times during the semester: the second week, when rosters were already settled, and the fifth week, which was not so late that it would interfere with midtermexam preparations. Fourth, both conflicts are foundational theoretical cases for Realism and have been used to demonstrate the utility and reach of the theory by its proponents. In both cases, there are clear Realist arguments for why conflict broke out and why it would break out again under similar conditions.

More disaggregated and dynamic gameplay allows students an opportunity to see non-Realist influences on international politics. To that end, we used Waltz's three-image typology as a framework to guide the simulation. ${ }^{1}$ The inclusion of first-, second-, and third-image constraints and influences complicated the simulation of international politics. Participants interacted across, within, and between teams, which created a more disaggregated role assignments reflected the first image, polity teams represented the second, and interteam relationships accounted for the third. By fleshing out the game around the skeleton of the three images, roles had multiple, overlapping, and simultaneous constraints and influences that each student had to think through before acting (see table 1).

In the assignment of roles, students acquired both identities and interests. In the first game, students were assigned an explicit Realist hierarchy of interests in which survival was the main priority, followed by increasing one's power and avoiding war. This was useful because students were still being introduced to Realism and Realist explanations of individual decision making. In the second simulation, they were allowed to form their own hierarchy of interests, which provided an opportunity to critically consider the naturalness and impact of Realist assumptions about state priorities. We expected that removing the hierarchy of interests would influence the outcome of the simulation and players' behavior.

During gameplay, students "role-played" their assigned characters within the context of polity teams (e.g., Athens or Austria). The structure of team decision making reproduced second-image constraints on behavior by creating rules specific to regime type, domestic interests, and identity groups. This information was presented in both the lectures and the readings. During the game, students were responsible for maintaining fidelity to these polity features. For example, a democracy makes decisions by majoritarian voting; martial polities have a military with greater internal power; and hierarchical polities defer final decisions to the monarch, yet also face the possibility of a rebellion or a coup. These domestic team dynamics allowed every player to have an important impact on the game.

The design of inter-polity gameplay used the third image. Each team was initially allocated an amount and type of military resources, consistent with the historical scenario described in the readings. The gameplay was organized in turns, in which teams could make any historically reasonable moves (e.g., issuing ultimatums, establishing or breaking alliances, and declaring war). Students interacted simultaneously during turns but came together periodically to make internal decisions about moves (Ben-Yehuda, Levin-Banchik, and Naveh 2015, 14). Every five minutes, polity teams had to submit their moves to the facilitator using action forms.

Two special moves were not immediately shared with the class. First were secret moves, which can involve hidden agreements, clandestine weaponization, and assassination attempts. The facilitator withheld these moves until it was necessary or appropriate to disclose them. Second were moves that have indeterminate results, such as troop mobilization, training, fighting, and other moves that require an outcome. For these, we drew inspiration from 
"board-game-like" designs (Bridge and Radford 2014; Goon 2011): the facilitator assigned a likelihood of success based on feasibility and used a dice roll to determine whether the move was successful.

These elements of game design collectively create a simulation that teaches students the three-image framework and the advantages and limitations of Realist theory. Students must consider their role, their team, and the international context in
2000; Smith and Boyer 1996, 690; Wedig 2010). Students were asked to e-mail the instructor a strategy for how they intended to behave in the simulation, based on the three images. As facilitators, our pre-simulation preparation was limited to planning a presentation of the rules, assembling notes on the readings and role assignments, providing maps, and compiling a list of possible interventions in case the simulation stalled.

\section{Students must consider their role, their team, and the international context in making decisions. Simulating a conflict scenario involving decisions about security allows students to reflect on Realism in practice.}

making decisions. Simulating a conflict scenario involving decisions about security allows students to reflect on Realism in practice. The game design also allows alternative, non-Realist sources of motivation, including pacifist and communitarian personalities, identity-based solidarity, domestic-audience constraints, culturally specific standards of appropriateness, and transnational affiliations. Maximizing the points at which students confront open-ended choices makes the ultimate outcome of the game indeterminate and ensures that they are not driven toward particular conclusions about Realism through the game design.

\section{GAME IMPLEMENTATION}

A few days before each section, students were assigned the role of a single actor within a team and asked to do the readings with that actor in mind (Asal and Blake 2006, 5; Newmann and Twigg
Before students arrived, instructors arranged the classroom into islands of tables reproducing the geographic position of each state. This facilitated communication and eavesdropping between contiguous teams. Students arrived without knowing the simulation's historical starting point, which prevented them from ignoring earlier parts of the conflict in the reading while still allowing alternate outcomes to emerge. In both cases, the specific historical starting point was a key turning point that sparked or accelerated the conflict (Asal and Blake 2006, 7).2 The facilitator briefly explained the rules, paused for questions, and then described the scenario, after which the simulation began.

During five-minute turns, students alternated among discussing strategies internally, deliberating about next moves, and sending delegates to other teams to make deals. They also decided on which moves they wanted to make based on any new information

Table 1

\section{Roles, Teams, and International Constraints}

\begin{tabular}{|c|c|c|c|c|}
\hline Team & Actors & 2nd-Image Structures & 3rd-Image Resources & 3rd-Image Structures \\
\hline Athens & $\begin{array}{l}\text { Pericles, Pro-Spartan General, } 3 \text { Assembly } \\
\text { members }\end{array}$ & Majoritarian & $\begin{array}{l}13,000 \text { hoplites available } \\
16,000 \text { spread out } \\
\text { 300 ships } \\
\text { Walls }\end{array}$ & Athens has final say \\
\hline Sparta & $\begin{array}{l}\text { King Archidamnus, Ephors, } 3 \text { Assembly } \\
\text { members }\end{array}$ & $\begin{array}{l}\text { Consensus, } \\
\text { rebellion risk }\end{array}$ & $\begin{array}{l}26,000 \text { hoplites } \\
4,000 \text { cavalry } \\
\text { Some ships }\end{array}$ & Flexible decision making \\
\hline Corinth & 2 Anti-Athens, 1 Pro-Athens & Majoritarian & $\begin{array}{l}2,500 \text { hoplites } \\
100 \text { ships }\end{array}$ & Colonial ties \\
\hline Potidaea & Rebels, Aristocrats & Consensus & Defensive walls & Colonial ties \\
\hline Corcyra & 3 Members & & $\begin{array}{l}2,000 \text { hoplites } \\
120 \text { ships }\end{array}$ & Colonial ties \\
\hline Germany & $\begin{array}{l}\text { Kaiser Wilhelm, Chief of Staff Moltke, } \\
\text { Chancellor Bethmann }\end{array}$ & $\begin{array}{l}\text { Chancellor has final say, } \\
\text { rebellion risk }\end{array}$ & 45 army corps & Monarchical kinship ties \\
\hline Austria-Hungary & $\begin{array}{l}\text { Emperor Francis Joseph, Count Von Berchtold, } \\
\text { Hoetzendorff, Prime Minister Tisza }\end{array}$ & $\begin{array}{l}\text { Emperor has final say, } \\
\text { rebellion risk }\end{array}$ & 16 army corps & Kinship ties \\
\hline Russia & $\begin{array}{l}\text { Tsar Nicolas II, Foreign Minister Sazonov, } \\
\text { Minister of War Sukhomlinov, Chief of Staff } \\
\text { lanushkevich }\end{array}$ & $\begin{array}{l}\text { Tsar has final say, } \\
\text { rebellion risk }\end{array}$ & $50+$ army corps & Ethnic ties, kinship ties \\
\hline Britain & $\begin{array}{l}\text { Foreign Secretary Edward Grey, Lord of the } \\
\text { Admiralty Winston Churchill, King George V }\end{array}$ & Majoritarian & 23 army corps & Democratic ties \\
\hline France & $\begin{array}{l}\text { Premiere Vivianni, President Poincarre, } \\
\text { General Joffre }\end{array}$ & Majoritarian & 21 army corps & Democratic ties \\
\hline Serbia & $\begin{array}{l}\text { Dragutin Dimitrijevic, King Peter, } \\
\text { Prime Minister Pasic }\end{array}$ & $\begin{array}{l}\text { King has final say, } \\
\text { rebellion risk }\end{array}$ & 5 army corps & Ethnic ties \\
\hline
\end{tabular}


that emerged during the turn. For example, students made secret pacts, publicly declared friendship or hostility, discussed mobilizing troops, fomented internal dissent, and attempted to break up alliances between other states. This can make a class somewhat chaotic, so it was important for the facilitator to move around the room to check that everyone was participating and that the simulation was progressing (Wedig 2010).

After the end of each five-minute turn, the facilitator restored order in the classroom. (A timer with an annoyingly loud alarm can accelerate this process.) Students then had one minute to decide on their moves and write down their action forms (Newmann and Twigg 2000, 837; Shellman and Turan 2006). The action forms were collected and read aloud by the facilitator; public moves can be recorded on the board by creating a table with teams on one axis and turns on another. Instructors also kept track of secret moves on a separate form. Special moves requiring an outcome were resolved by a dice roll before the next team's move was announced. Examples of special moves include secret naval missions, assassination attempts, deployment of anthrax, and sending spies. After all moves were declared and resolved,
There are many possible explanations for variation in the outcomes and survey results. Readings and lecture material can provide specific and distinctive resources on which students based their behavior. The historical conditions before each simulation may have altered their ability to change simulation outcomes. Increased social familiarity and the presence of different students in leadership roles may have made them more comfortable about being creative. Finally, the absence of war may have been a result of time limitations rather than an ultimate outcome. Despite all of these influences, limited insights can be drawn about the impact of game design on outcomes and survey results.

The first survey question asked students to assess the value of Realist theory. After both simulations, most indicated that Realism was a useful theory for understanding international politics. However, after the second simulation, more students indicated that the simulation led them to reflect on Realist assumptions of rational decision making and the primacy of security motives. For example, some students indicated that decision making was driven by emotions and normative commitments rather than rational security seeking.

\section{After both simulations, most indicated that Realism was a useful theory for understanding international politics. However, after the second simulation, more students indicated that the simulation led them to reflect on Realist assumptions of rational decision making and the primacy of security motives.}

the instructor announced the start of the next turn and students resumed gameplay. The game continued in this manner until the time allotted for the simulation ended.

The simulation ended with a short debriefing guided by the facilitator, in which students were given a chance to reflect on the outcome of gameplay. This involved a discussion of what occurred, including any secret moves, and an opportunity for students to vent frustrations and express their excitement. The facilitator guided this conversation by focusing on "teachable moments" that illustrate and challenge certain theoretical concepts (Asal 2005, 370; Newmann and Twigg 2000, 841; Wedig 2010). An especially useful place to start was asking students to explain the difference between the actual historical outcome and what occurred during the game.

\section{ASSESSMENT}

We drew on two sources of information to assess the achievement of our learning objectives. First, differences in outcomes between the two scenarios indicated whether it mattered to make Realist priorities explicit. War broke out in all four cases of the Peloponnesian simulation, whereas a continent-wide war broke out in only one of the four World War I simulations. ${ }^{3}$ Second, we designed a voluntary, anonymous online survey, distributed by e-mail after each of the two simulations. Our survey included one open-ended question to measure changes in student impressions of Realism and two multiple-choice questions to capture the role of the three images in gameplay. The post-simulation survey was imperfect but informative. The first and second surveys had response rates of $70 \%$ and $52 \%$, respectively.
The two questions about the three images of analysis provided insight into how students understood the dynamics of international politics. They reported that the second image had the most dominant influence on individual decision making (see table 2). In contrast, most students indicated that the third image had the greatest impact on the game's overall outcome. These results were consistent across both surveys. The distribution of responses indicates that the simulation modeled a dynamic international system, such that even first- and second-image constraints that were not determinative still conditioned the course of international events.

Variations in simulation outcomes and survey responses indicate that varying game design successfully led students to acquire

Table 2

Influence of Images across War Scenarios

\begin{tabular}{|c|c|c|c|}
\hline & Peloponnesian War & World War I & $\%$ Change \\
\hline & \multicolumn{3}{|c|}{$\begin{array}{l}\text { Which image had the greatest influence } \\
\text { on your decision making? }\end{array}$} \\
\hline 1st Image & $20 \%$ & $28 \%$ & $+8 \%$ \\
\hline 2nd Image & $43 \%$ & $39 \%$ & $-4 \%$ \\
\hline \multirow[t]{2}{*}{ 3rd Image } & $37 \%$ & $33 \%$ & $-4 \%$ \\
\hline & \multicolumn{3}{|c|}{$\begin{array}{l}\text { Which image had the greatest impact on the } \\
\text { game's outcome overall? }\end{array}$} \\
\hline 1st Image & $22 \%$ & $15 \%$ & $-7 \%$ \\
\hline 2nd Image & $23 \%$ & $31 \%$ & $+8 \%$ \\
\hline 3rd Image & $55 \%$ & $54 \%$ & $-1 \%$ \\
\hline
\end{tabular}


a more critical appreciation of Realism as a theory of international politics. Survey results from both the open-ended and multiplechoice questions suggest that, in particular, the removal of an explicit hierarchy of interests in the second game created an opportunity for students to critically reflect on how the internalization of Realist hierarchies of interest could increase the chances of conflict. They reported that the removal of a hierarchy of interests allowed them to avoid war. ${ }^{4}$ We can surmise that students replaced the explicit Realist hierarchy of interests with a more nuanced set of motivations in the second game. This conclusion also is supported by changes in the response rate about the role of the first image in student decision making. When the hierarchy of interests was removed in the second game, students found first-image considerations more salient to their own decision making. This suggests that the rule change prompted them to question the naturalness of Realist priorities and values for international actors.

Other results from the survey were less useful for evaluating the achievement of our learning objectives, but they suggest future avenues for research and refinement of the game design.

\section{CONCLUSION}

Our game improves on existing simulations designed to teach Realism by offering students opportunities to critically reflect on the assumptions and limitations of Realist theory. Our basic game design could be adjusted to teach other theories of international politics; however, the scenarios we chose are optimal for teaching and critically evaluating Realist precepts because these wars are paradigmatic cases for Realist explanations. Our survey results reported several findings for which we have no explanation. A consistent majority of students reported that the third image had the most impact on outcomes. This suggests an opportunity for testing the influence of neo-Realism, in particular, on students' understanding of international politics. Going forward, we may want to add survey questions that help us understand why students respond in this manner. In general, the addition of control groups and a pre-simulation survey could support stronger conclusions about the impact of game design on learning objectives.

\section{ACKNOWLEDGMENTS}

The authors thank Steven David, Victor Asal, Hemda Ben-Yehuda, and Rex Brynen for their helpful feedback and comments. We also thank the anonymous reviewers for helpful comments that improved this article.

\section{NOTES}

1. The three-image framework for analysis was originally used to explain the outbreak of conflict in international politics. The first image explains conflict at the level of human nature or individual traits, the second image at the level of domestic attributes of particular states, and the third image at the level of the international system (Waltz 2001).

2. The starting point for the Peloponnesian War simulation was the long winter of 434 BC. In response to an Athenian ultimatum, Potidaea (an Athenian ally) sent emissaries to Sparta asking for aid. This historically led to the two hegemons entering into a region-wide conflict. The starting point for the World War I simulation was the assassination of Franz Ferdinand. Assigned chapters from MacMillan (2014) outlined the identity, domestic, dynastic, and structural conditions in the lead-up to the war.

3. Even when war did not break out, gameplay often included violence, such as assassination attempts, beheadings, and sabotage.

4. Although Realists do not always expect war to break out, the Realist literature on World War I would expect war to break out under the same conditions (Clark 2013; Lebow 2014).

\section{REFERE N C E S}

Asal, Victor. 2005. "Playing Games with International Relations." International Studies Perspectives 6 (3): 359-73.

Asal, Victor, and Elizabeth L. Blake. 2006. "Creating Simulations for Political Science Education." Journal of Political Science Education 2 (1): 1-18.

Asal, Victor, and Jayson Kratoville. 2013. "Constructing International Relations Simulations: Examining the Pedagogy of IR Simulations through a Constructivist Learning Theory Lens." Journal of Political Science Education 9 (2): 132-43.

Baranowski, Michael, and Kimberley A. Weir. 2015. "Political Simulations: What We Know, What We Think We Know, and What We Still Need to Know." Journal of Political Science Education 11 (4): 391-403.

Ben-Yehuda, Hemda, Luba Levin-Banchik, and Chanan Naveh. 2015. World Politics Simulations in a Global Information Age. Ann Arbor: University of Michigan Press.

Biersteker, Thomas. 2009. “The Parochialism of Hegemony.” In International Relations Scholarship around the World, eds. Arlene B. Tickner and Olae Waever, 308-27. New York: Routledge.

Bridge, David, and Simon Radford. 2014. "Teaching Diplomacy by Other Means: Using an Outside-of-Class Simulation to Teach International Relations Theory." International Studies Perspectives 15 (4): 423-37.

Chapin, Wesley D. 1998. “The Balance of Power Game." Simulation \& Gaming 29 (1): 105-12.

Clark, Christopher. 2013. The Sleepwalkers: How Europe Went to War in 1914. New York: Harper Collins.

Giovanello, Sean P., Jason A. Kirk, and Mileah K. Kromer. 2013. "Student Perceptions of a Role-Playing Simulation in an Introductory International Relations Course." Journal of Political Science Education 9 (2): 197-208.

Glazier, Rebecca A. 2011. "Running Simulations without Ruining Your Life: Simple Ways to Incorporate Active Learning into Your Teaching." Journal of Political Science Education 7 (4): 375-93.

Goon, Michael. 2011. "Peacekeeping the Game." International Studies Perspectives $12(3): 250-72$.

Kagan, Donald. 2004. The Peloponnesian War. New York: Penguin Books.

Lebow, Richard Ned. 2014. "What can International Relations Theory Learn from the Origins of World War I?" International Relations 28 (4): 387-410

MacMillan, Margaret. 2014 (reprint edition). The War That Ended Peace: The Road to 1914. New York: Random House Trade Paperbacks.

Mearsheimer, John. 2001. The Tragedy of Great Power Politics. New York: W. W. Norton \& Company.

Morgenthau, Hans J. [1948] 2006. Politics among Nations: The Struggle for Power and Peace. New York: McGraw Hill.

Newmann, William W., and Judyth L. Twigg. 200o. "Active Engagement of the Intro IR Student: A Simulation Approach.” PS: Political Science E Politics $33(4): 835-42$

Reilly, David A. 2003. "The Power Politics Game: Offensive Realism in Theory and Practice." Simulation \& Gaming 34 (2): 298-305.

Remarque, Erich Maria, and A. W. Wheen. 1991. All Quiet on the Western Front New York: Ballantine Books.

Sampson, Aaron Beers. 2002. "Tropical Anarchy: Waltz, Wendt, and the Way We Imagine International Politics.” Alternatives: Global, Local, Political 27 (4): 429-57.

Schweller, Randall L. 1997. "New Realist Research on Alliances: Refining, Not Refuting, Waltz's Balancing Proposition.” American Political Science Review 91 (4): 927-30.

Shellman, Stephen M., and Kürșad Turan. 2006. "Do Simulations Enhance Student Learning? An Empirical Evaluation of an IR Simulation." Journal of Political Science Education 2 (1): 19-32.

Sjoberg, Laura. 2012. "Gender, Structure, and War: What Waltz Couldn't See." International Theory 4 (1): 1-38.

Smith, Elizabeth T., and Mark A. Boyer. 1996. "Designing In-Class Simulations.” PS: Political Science \& Politics 29 (4): 690-4

Stoessinger, John George. 2011. Why Nations Go to War. Boston: Wadsworth.

Thucydides. [1954] 1972. History of the Peloponnesian War. (R. Warner, Trans.) New York: Penguin Books.

Waltz, Kenneth N. 2001. Man, the State, and War: A Theoretical Analysis. New York: Columbia University Press.

Wedig, Timothy. 2010. "Getting the Most from Classroom Simulations: Strategies for Maximizing Learning Outcomes.” PS: Political Science \& Politics 43 (3): $547-55$. 